\title{
Development Strategy of PT XYZ in the Inflight Catering Industry
}

\author{
Martiana Kartika Dewi ${ }^{1}$, Bonar Sinaga ${ }^{2}$, Setiadi Djohar ${ }^{3}$ \\ ${ }^{1}$ Post Graduate, School of Business, Bogor Agricultural University, Indonesia 16151 \\ ${ }^{2}$ School of Business, Bogor Agricultural University, Indonesia16151 \\ ${ }^{3}$ PPM School of Management, J1. Menteng Raya 9-19 Jakarta, Indonesia
}

\begin{abstract}
Strategy is a process of determining a plan that focuses on the organization long-term goals, accompanied by the preparation of a way or an effort that must be done in achieving the goals. The objectives of this research were (1) analyzing the advantages of PT $X Y Z$ Unit Jakarta(CGK) for company development (2) analyzing and formulating the right business development strategy for PT XYZ Unit Jakarta(CGK). The research used case-study method (observational case study) and IFE and EFE analysis for the preparation of IE Matrix to obtain alternative strategy. Selection of strategy priorities by using Quantitative Strategic Planning Matrix (QSPM). The results showed that PT XYZ is able to provide good response tocompany's external and internal factors. An alternative strategy result at the matching stage was the intensive strategy of market penetration, market development, and product development or integration strategy that is backward integration, forward integration and horizontal integration. The result of QSPM matrix showed that priority strategy to PT XYZ is developing one-stop service packages thatmatched to company's condition and being developed to be one of business development strategy. PT XYZ long term strategywas developing markets for the non-aviation sector as the inflights catering market was captive and requires a long period to develop.
\end{abstract}

Keywords: Strategic Planning, IFE, EFE, IE Matrix, QSPM, Inflight Catering

\section{Introduction}

The aviation industry has an important role for Indonesia economic growth since it was an archipelagic country consisting of 13,000 islands with sea area reaches $60 \%$. Indonesia geographically has a very strategic position because it is located between two continents and oceans. Indonesia needs to be supported by various means of good transportation. Air transportation is one of the important means of transportation today. Air transportation play an important role as inter-island liaison and to link countries around the world in trade, tourism, international relations for economic development. Air transportation facilities in its development become one of the bearer of the image of a country.

Air transportation is currently a major transportation alternative for people to travel. Soekarno-Hatta Airport is the gate of air transportation in Indonesia. The number of passengers using air transportation through Soekarno-Hatta Airport Tangerang tends to increase from 2006 to 2016

Airline service becomes one of the attractions of passengers in determining the selection of airlines. The airlines are trying to improve the service to passengers, especially for airlines with full service concept of both domestic airlines and foreign airlines. The services provide on board are passenger meals called meals on board. Meals served on airplane trips are the end products of inflight catering services.

PT XYZ is a subsidiary of the state-owned airline PT Garuda Indonesia (Persero) Tbk that engaged in the catering aviation business. PT XYZ is currently Indonesia's largest Inflight Caterer Company thsat has 9 units of inflight Catering business including Jakarta (CGK), Denpasar
(DPS), Surabaya (SUB), Medan (KNO), Yogyakarta (JOG), Bandung (BDO), Balikpapan (BPN), Pekanbaru (PKU), and Lombok (LOP). The CGK Unit is the largest unit with average meal uplift per month and flight frequency per month reaches $53 \%$ of the total inflight Catering units owned by PT XYZ. The CGK unit produces approximately 40,000 meals per day. The number of flights coming from Soekarno-Hatta Airport reaches 53\% of the total number of total flights served by PT XYZ as a whole. The average number of flights served by PT XYZ reaches 200 flights per day

The inflight catering Business operated by PT XYZ are business to business within a certain period of cooperation agreement. Customer demands quality and good service from PT XYZ as stipulated in the cooperation agreement between both parties. Customer requires the existence of Service Level Agreement which explains fines / sanctions due to negligence made by PT XYZ related to products and services, therefore PT XYZ strives to meet the customer's requirement especially the CGK unit which currently serves 24 airlines both foreign and local airlines. The financial performance of the company is one of the benchmarks of the company's success in running the business owned by Revenue in the period 2012 to 2016 has increased by $48.64 \%$, while for gross profit and net profit tends to decrease starting from 2014. Profit decrease in 2016 significant enough to reach $29.90 \%$ for gross profit and $65.14 \%$ for net profit compared to the year. It indicates the inefficiency of resource usage.

The Competition with major competitor in the Inflight Catering has increased in the last five years. It was marked by airlines customers who began to take into account the competitors of PT XYZ SERA unit and the switching of three PT XYZ customer units to the competitor company from 2015 to 2016, namely Qatar Airways (QR) in January

\section{Volume 6 Issue 12, December 2017}

\section{www.ijsr.net}




\section{International Journal of Science and Research (IJSR) \\ ISSN (Online): 2319-7064}

Index Copernicus Value (2016): 79.57 | Impact Factor (2015): 6.391

2015, All Nippon Airways (NH) in June 2015 and China Shoutern Airlines (CZ) in January 2016. Qatar Airways and ANA are two airlines including five customer airlines with the largest revenue of PT XYZ Unit CGK

Comprehensive strategies are needed as the basis for companies in making decisions and remedial measures to deal with an increasingly complex business environment. PT XYZ Unit CGK needs to formulate a business development strategy to ensure the sustainability of the company's business. Strategies that need to be developed should include an analysis of the opportunities and threats of the external environment and internal readiness of the company in the face of possible changes. The strategy should be able to be communicated simultaneously to all members in the company covering all aspects of the company's business activities. The objectives of this research are (1) to analyze the competitive advantage of PT XYZ Unit Jakarta (CGK) for company development, (2) to analyze and formulate the right business development strategy for PT XYZ Unit Jakarta (CGK).

\section{Research Methods}

This study uses descriptive techniques, in the form of case studies supported by literature studies (textbooks, magazines, scientific journals and relevant Internet information). Descriptive method aims to describe a phenomenon or the nature of something that is going on at the time of research done and examine the causes of a particular symptom and to answer questions that concern something at the time of the research process. The case study is a qualitative in-depth study of an object, whether individual, corporate or government organization or a university (Sumarwan et al, 2014).

The research is focused on designing the analysis of the influence of external environment and internal environment as well as the competitive advantage of PT XYZ in the inflight catering industry, as well as the formulation of business development strategy to maintain the company's business continuity as well as the development of the Inflight Catering industry.

The method used in this research is the case study method (observational case study) with a qualitative approach that combines the input of qualitative and quantitative data. This study begins with case studies that generate qualitative data input by conducting structured interviews with resource persons and analyzed by using IFE and EFE to then be used for the preparation of IE Matrix until diperleh alternative strategy. Selection of strategy priorities by using Quantitative Strategic Planning Matrix (QSPM).

This research has been conducted at PT XYZ located at Soekarno-Hatta International Airport, Indonesia. The selection of research sites was purposively considerate that PT XYZ is the market leader of the Inflight catering industry in Indonesia that continues to grow along with the development of air transportation. The data used are primary data and secondary data. The role of primary data is as key information in answering research objectives. Primary data in this study was obtained through interviews with the parties involved directly in the formulation of corporate development strategies using questionnaire instrument. And secondary data includes literature studies, such as journals, theses, and other sources of information relevant to this research

This research is limited to formulation of strategy based on case study at PT XYZ by involving top management of company as internal party and from external party represented by expert from customer's company, perpetrator in Retail Company and customer of PT XYZ. The research was conducted at PT XYZ, which is located in Jakarta. The selection of PT XYZ is deliberately chosen based on the formulation of problems. The consideration is the availability of data and willingness of the company's management to be examined its strategic study. Determination of respondents is using purposive sampling based on the company's current organizational structure that is part of the Board of Director and management of PT XYZ Unit Jakarta (GCK). Respondents are selected based on the consideration of the competence and capacity of each field. The list of respondents is presented in Table 1 .

Table 1: List of Expert Respondents

\begin{tabular}{|c|c|c|}
\hline Expert Respondents & Organization & Remarks \\
\hline Director of Operations & PT XYZ & Internal \\
\hline GM of Unit Jakarta (CGK) & PT XYZ & Internal \\
\hline Executive Manager & PT XYZ & Internal \\
\hline Business Development Specialist & PT XYZ & Internal \\
\hline Mr. XX & $\begin{array}{c}\text { Customer of } \\
\text { PT XYZ }\end{array}$ & $\begin{array}{c}\text { Eskternal/ } \\
\text { Eksekutif }\end{array}$ \\
\hline
\end{tabular}

\section{Data Analysis and Processing Method}

The analysis that conducted in this research were qualitative analysis and quantitative analysis aimed at gathering views on the company's condition in the current challanges through experts and practitioners working directly on the Inflight Catering industry. Instrument of analysis used in internal and external analysis of the company are Internal Factor Evaluation (IFE), External Factor Evaluation (EFE), and IE Matrix, determined the right $\mathrm{c}$ business development strategy using Quantitative Strategic Planning Matrix (QSPM). Stages of this research consists of several the process are as follow:

1) Input stage: VRIO analysis (internal factors) and PESTEL analysis (external factors).

2) Matching stage: IE matrix based on two key dimensions. Total IFE weight on $\mathrm{x}$ axis and total EFE weight score on y axis.

3) Stages of decision making: determining the best priority strategy using quantitative strategic planning matrix or known as QSPM.

\section{Result}

\section{Internal Factors Analysis}

General description of PT XYZ internal factor condition is obtained from VRIO analysis. The company must be able to recognize and optimize its resources. Resource optimization owned must be embodied in a business strategy of the company and translated into business activities activities at the company. Barney (1991) states that resources are assets, competencies, skills or knowledge controlled by the

\section{Volume 6 Issue 12, December 2017}




\section{International Journal of Science and Research (IJSR) \\ ISSN (Online): 2319-7064 \\ Index Copernicus Value (2016): 79.57 | Impact Factor (2015): 6.391}

company. These resources become a force for the company if it can make the company has a competitive advantage. Resources can be a disadvantage if the company does not have the capacity to do something even if the competitor has that capacity.

Table 2: Results of VRIO Analysis

\begin{tabular}{|c|c|c|c|c|c|c|}
\hline Resource & Value? & Rare? & $\begin{array}{c}\text { Costly to } \\
\text { Imitate? }\end{array}$ & Organized? & Status & $\begin{array}{c}\text { Strength / } \\
\text { Weakness }\end{array}$ \\
\hline Certification and standardization & $\mathrm{V}$ & $\mathrm{V}$ & $\mathrm{X}$ & $\mathrm{X}$ & Competitive Advantage & Strength \\
\hline Large facilities of production & $\mathrm{V}$ & $\mathrm{V}$ & $\mathrm{V}$ & $\mathrm{V}$ & Sustained Competitive Advantage & Strength \\
\hline Experienced more than 40 yeas & $\mathrm{V}$ & $\mathrm{V}$ & $\mathrm{V}$ & $\mathrm{V}$ & Sustained Competitive Advantage & Strength \\
\hline Part of Garuda Indonesia (Skyteam member) & $\mathrm{V}$ & $\mathrm{V}$ & $\mathrm{V}$ & $\mathrm{V}$ & Sustained Competitive Advantage & Strength \\
\hline Good reputation to customers & $\mathrm{V}$ & $\mathrm{V}$ & $\mathrm{V}$ & $\mathrm{V}$ & Sustained Competitive Advantage & Strength \\
\hline Weak implementation of strategy & $\mathrm{X}$ & $\mathrm{X}$ & $\mathrm{X}$ & $\mathrm{X}$ & Competitive disadvantage & Weakness \\
\hline Does not have an integrated system & $\mathrm{V}$ & $\mathrm{X}$ & $\mathrm{X}$ & $\mathrm{X}$ & Competitive Parity Temporary & Weakness \\
\hline Number of large human resources (labor intensive) & $\mathrm{V}$ & $\mathrm{X}$ & $\mathrm{X}$ & $\mathrm{X}$ & Competitive Parity Temporary & Weakness \\
\hline The idea of service concept is not developed & $\mathrm{V}$ & $\mathrm{X}$ & $\mathrm{X}$ & $\mathrm{X}$ & Competitive Parity Temporary & Weakness \\
\hline Lack of ability to innovate & $\mathrm{X}$ & $\mathrm{X}$ & $\mathrm{X}$ & $\mathrm{X}$ & Competitive disadvantage & Weakness \\
\hline
\end{tabular}

Based on the identification of internal factors of the company using VRIO approach, the internal strengths of PT XYZ are: (1) certification and standardization, (2) production facilities (3) experience in catering, (4) part of Garuda Indonesia Airlines (Skyteam member), (5) good reputation to airlines customers. Weaknesses identified in PT XYZ are as follows: (1) corporate strategy, (2) integrated systems, (3) large (labor-intensive) human resources, (4) ideas (5) ability ofmaking innovations.

\section{External Factors Analysis}

External factors analysis used in this research is PESTEL approach. The PESTEL framework can be used to analyze various factors in a corporate macro environment. The higher the likelihood of change that will occur and the greater the impact of these changes, the greater the factor to be considered in the planning of the company. Companies can create strategies by analyzing macro environmental factors. PESTEL analysis is an analysis of the political, economic, social and technological conditions that may affect the company's activities and performance. While the PESTEL model enters the environmental and legal aspects as an external factor that is likely to have an impact on the company (Rothaermel, 2012).

The results of PESTEL analysis indicate that the opportunities in PT XYZ are: (1) visa-free visit of 169 countries to Indonesia, (2) agreement of "Asean Open Skies", (3)development planning of air facilities (4) opportunity of non inflight food and beverage market industry, (5) frozen food technology development opportunities. The threat of PT XYZ is based on an analysis of external factors: (1) captive markets (2) inflation and increasing minimum wages of workers each year (3) there is no clear government policy related to the catering industry (4) import policy by the government (5) the development of low-cost airlines (LCC). PT XYZ's response to external factors is presented in Table 3 .
Table 3: Response to External Factors

\begin{tabular}{|c|c|}
\hline External Factors & Response \\
\hline \multicolumn{2}{|l|}{ Opportunities } \\
\hline $\begin{array}{l}\text { Visa-free visit of } 169 \text { countries } \\
\text { to Indonesia }\end{array}$ & $\begin{array}{l}\text { Companies respond to } \\
\text { opportunities well }\end{array}$ \\
\hline $\begin{array}{c}\text { Agreement of "Asean Open } \\
\text { Skies" }\end{array}$ & $\begin{array}{c}\text { Companies respond to } \\
\text { opportunities well }\end{array}$ \\
\hline $\begin{array}{l}\text { Development planning of air } \\
\text { facilities }\end{array}$ & $\begin{array}{l}\text { Companies respond to } \\
\text { opportunities well }\end{array}$ \\
\hline $\begin{array}{l}\text { Opportunity of non inflight food } \\
\text { and beverage market industry }\end{array}$ & $\begin{array}{l}\text { The company has not been } \\
\text { focused on opportunities }\end{array}$ \\
\hline $\begin{array}{c}\text { Frozen food technology } \\
\text { development opportunities }\end{array}$ & $\begin{array}{l}\text { The company has not been } \\
\text { focused on opportunities }\end{array}$ \\
\hline \multicolumn{2}{|l|}{ Ancaman } \\
\hline $\begin{array}{l}\text { Captive markets of inflight } \\
\text { catering industry }\end{array}$ & $\begin{array}{c}\text { The company's response does } \\
\text { not match the expected outcome }\end{array}$ \\
\hline $\begin{array}{l}\text { Inflation and increasing } \\
\text { minimum wages }\end{array}$ & $\begin{array}{l}\text { The company has not been } \\
\text { focused on opportunities }\end{array}$ \\
\hline $\begin{array}{l}\text { There is no clear government } \\
\text { policy related to the catering } \\
\text { industry }\end{array}$ & $\begin{array}{l}\text { The company's response does } \\
\text { not match the expected outcome }\end{array}$ \\
\hline $\begin{array}{l}\text { Import policy by the } \\
\text { government }\end{array}$ & $\begin{array}{l}\text { The company's response does } \\
\text { not match the expected outcome }\end{array}$ \\
\hline $\begin{array}{l}\text { The development of low-cost } \\
\text { airlines (LCC) }\end{array}$ & $\begin{array}{l}\text { The company has not been } \\
\text { focused on opportunities }\end{array}$ \\
\hline
\end{tabular}

\section{Evaluation of Internal Factors}

The Internal Factor Evaluation Matrix is a systematic method of analysis to determine the firm's strategic advantage factors (Sholihin, 2014). The main factors in the internal environment of the company are then weighted by using the IFE Matrix. The weights in the IFE Matrix evaluation show the level of importance of internal factors with weights ranging from 0.00 to 1.00 . Weight 0.0 puts out internal factors not important in the company's development effort, while the value of 1.00 indicates that the factor is a very important factor related to the development effort of the company. Rating with a value of 1 - 4 shows PT XYZ in exploiting its strengths and overcoming the weaknesses it has in its catering business activities. Scores obtained on the IFE Matrix make an overview for companies in optimizing strengths and minimizing weaknesses in determining corporate strategy. The result of internal factor evaluation of PT XYZ based on the data processing is presented in Table 4. 


\section{International Journal of Science and Research (IJSR) \\ ISSN (Online): 2319-7064 \\ Index Copernicus Value (2016): 79.57 | Impact Factor (2015): 6.391}

Table 4: IFE Matrix

\begin{tabular}{|c|c|c|c|c|}
\hline No. & Key Internal Factors (v) & \begin{tabular}{|l|}
$\begin{array}{l}\text { Weigh } \\
\text { (a) }\end{array}$ \\
\end{tabular} & $\begin{array}{l}\text { Rating } \\
\text { (b) }\end{array}$ & $\begin{array}{l}\text { Score } \\
(\mathrm{axb})\end{array}$ \\
\hline \multicolumn{5}{|c|}{ Strength } \\
\hline 1 & Certification and standardization & 0,062 & 3 & 0,186 \\
\hline 2 & Large facilities of production & 0,109 & 4 & 0,436 \\
\hline 3 & Experienced more than 40 yeas & 0,074 & 4 & 0,297 \\
\hline 4 & $\begin{array}{c}\text { Part of Garuda Indonesia(Skyteam } \\
\text { member) }\end{array}$ & 0.081 & 4 & 0,322 \\
\hline 5 & Good reputation to customers & 0.082 & 4 & 0.327 \\
\hline \multicolumn{5}{|c|}{ Weakness } \\
\hline 1 & Weak implementation of strategy & 0,143 & 1 & 0,143 \\
\hline 2 & $\begin{array}{l}\text { Does not have an integrated } \\
\text { system }\end{array}$ & 0,134 & 2 & 0,268 \\
\hline 3 & $\begin{array}{c}\text { Number of large human resources } \\
\text { (labor intensive) }\end{array}$ & 0,123 & 2 & 0,245 \\
\hline 4 & $\begin{array}{c}\text { The idea of service concept is not } \\
\text { developed }\end{array}$ & 0,100 & 2 & 0,201 \\
\hline 5 & Lack of ability to innovate & 0,093 & 1 & 0,093 \\
\hline \multicolumn{2}{|r|}{ Total } & 1,000 & & 2,518 \\
\hline
\end{tabular}

IFE matrix in Table 4 shows that the score achieved is more than the average of 2.518. A score above 2.5 indicates that PT XYZ has good internal conditions. Companies are able to harness the power and minimize weaknesses, but still in the medium category. The main factor of PT XYZ which become the main strength is Facility with big production capacity (S2) with score 0,436. Major strengths are needed as a basis for developing strategies to cope with the dynamics of the catering business. The main weakness of PT $\mathrm{XYZ}$ based on weakness with lowest score is Lack of ability to innovate (W5).

\section{Evaluation of External Factors}

The external environmental analysis undertaken includes analytical activities covering the major threats and opportunities facing the company. External factor analysis is required in the formulation of corporate strategy to optimize opportunities and reduce the impact of threats faced by the company. External environmental analysis aims to identify potential opportunities and threats to an organization (Robinson, 2008). The external factors of the company are in fact very dynamic and rapidly changing due to the influence of various factors with complex interactions. External factors are generally factors that are beyond the control of the company.

The EFE matrix returns the highest and lowest scores by weighting and rating methods. The weighting results show the importance of an external factor with weights ranging from 0.00 to 1.00 . The rating rating indicates PT XYZ's response to the opportunities and threats that exist in the company's development strategy. Scores earned on the EFE Matrix reflect the company's ability to take advantage of opportunities and address potential threats. The results of the evaluation of external factors of PT XYZ based on the results of questionnaire data processing on the experts summarized in EFE Matrix presented in Table 5.

Table 5: EFE Matrix

\begin{tabular}{|c|c|c|c|c|}
\hline No. & Key External Factors (v) & $\begin{array}{c}\text { Weigh } \\
(\mathrm{a})\end{array}$ & $\begin{array}{c}\text { Rating } \\
\text { (b) }\end{array}$ & $\begin{array}{c}\text { Score } \\
\text { (axb) }\end{array}$ \\
\hline 1 & $\begin{array}{c}\text { Bebas Visa Kunjungan 169 Negara } \\
\text { ke Indonesia }\end{array}$ & 0,078 & 4 & 0,312 \\
\hline 2 & Perjanjian “Asean Open Skies' & 0,088 & 4 & 0,352 \\
\hline 3 & $\begin{array}{c}\text { Rencana pengembangan fasilitas } \\
\text { Bandar Udara }\end{array}$ & 0,113 & 4 & 0,453 \\
\hline 4 & $\begin{array}{c}\text { Terbukanya pasar industri makanan } \\
\text { dan minuman non penerbangan }\end{array}$ & 0,098 & 2 & 0,196 \\
\hline 5 & $\begin{array}{c}\text { Peluang pengembangan teknologi } \\
\text { frozen food }\end{array}$ & 0,085 & 2 & 0,169 \\
\hline 1 & $\begin{array}{c}\text { Pasar industri penerbangan yang } \\
\text { terbatas (captive) }\end{array}$ & 0,112 & 3 & 0,337 \\
\hline 2 & $\begin{array}{c}\text { Inflasi dan kenaikan upah minimum } \\
\text { pekerja }\end{array}$ & 0,124 & 4 & 0,497 \\
\hline 3 & $\begin{array}{c}\text { Belum ada kebijakan pemerintah } \\
\text { yang jelas }\end{array}$ & 0,103 & 3 & 0,310 \\
\hline 4 & $\begin{array}{c}\text { Kebijakan pembatasan impor oleh } \\
\text { pemerintah }\end{array}$ & 0,095 & 3 & 0,284 \\
\hline 5 & $\begin{array}{c}\text { Berkembangnya maskapai berbiaya } \\
\text { rendah }\end{array}$ & 0,103 & 2 & 0,207 \\
\hline & Total & 1,000 & & 3,118 \\
\hline
\end{tabular}

The total score on the EFE Matrix above was obtained at 3.118. The total score obtained is a total score that is above average. This condition illustrates that PT XYZ is able to take advantage of existing opportunities to minimize the threats that may arise and affect PT XYZ. External factors that become the main opportunity is the Airport facility development plan (P3) with a score of 0.453. External factors that become the biggest ancman with the lowest score is the development of low-cost carrier (T5). This threat is a constraint related to the company's efforts to improve the company's performance as an effort to improve profitability for the sustainability of the company's business activities.

\section{Recommended Business Strategy}

The matching stage is to match the results of evaluation of internal and external factors (IFE and EFE). The IE matrix is based on two key dimensions: the total IFE weight score on the $\mathrm{x}$ axis and the total EFE weight score on the $\mathrm{y}$ axis. IE Matrix presents the various divisions of an organization in the nine celsl view. The results of internal and external factor matching (IFE and EFE) of PT XYZ are presented in Figure 1. 
International Journal of Science and Research (IJSR)

ISSN (Online): 2319-7064

Index Copernicus Value (2016): 79.57 | Impact Factor (2015): 6.391

\begin{tabular}{|c|c|c|c|c|c|}
\hline & & $\begin{array}{c}\text { Kuat } \\
3.0-4.0\end{array}$ & $\begin{array}{c}\text { Sedang } \\
2.00-2.99\end{array}$ & & $\begin{array}{c}\text { Lemah } \\
1.00-1.99\end{array}$ \\
\hline & 4.0 & & & 2.0 & 1.0 \\
\hline $\begin{array}{l}\text { Tinggi } \\
3.0-4.0\end{array}$ & & I & II (PT XYZ) & & III \\
\hline $\begin{array}{c}\text { Sedang } \\
2.0-2.99\end{array}$ & 5.0 & IV & $\mathrm{V}$ & & VI \\
\hline $\begin{array}{c}\text { Rendah } \\
1.0-1.99\end{array}$ & 1.0 & VII & VIII & & IX \\
\hline
\end{tabular}

Figure 1: IE Matrix

The IE matrix in Figure 1 shows that the total score obtained in the IFE Matrix belongs to the moderate group of 2.611 with the total score in the EFE Matrix belonging to the high group of 3.118 so that PT XYZ as the IE Matrix is in cell number III. The matching results included in cell number III can be described as a company in a growing and membagun position. The right strategy for matching results is an intensive strategy strategy that is market penetration, market development, and product development or integration strategy that is backward integration, forward integration and horizontal integration (David, 2011).

\section{Determination of Business Strategy of PT XYZ (QSPM)}

The determination of alternative strategies is the final step in strategy formulation. The company evaluates and then chooses the best strategy that best matches the internal and external environment of the company. Determination of the decision is done by questionnaires in which there is an alternative strategy to later known the value of the respondent's interest in alternative strategies and external factors (opportunities - threats) that have been mapped previously. Taking this stage questionnaire focuses on the representatives of the company's top ranks.

QSPM allows an alternative evaluation of strategies based on external and internal factors identified previously Mirijakani et al (2014). The use of QSPM matrices has several advantages that lie in the components of strategies that can be evaluated gradually or simultaneously. In the QSPM Matrix analysis there is no limit to how many strategic alternatives can be evaluated using QSPM.

Another advantage of QSPM matrix analysis is that it can integrate various strategies from relevant internal and external factors into the decision-making process. The use of QSPM can reduce the neglect of a key factor or nonconformance in weighting.

The purpose of QSPM is to know the attractiveness of the strategy initiatives formulated for the next selected strategy that best suits the internal conditions (strengths weaknesses) and the external environment (threats). An alternative strategy based on the IE Matrix matching results that have been made for strategy recommendations for PT $\mathrm{XYZ}$ is an intensive strategy or integration strategy. Alternative strategies obtained by considering the strengths - weaknesses as internal factors and opportunities and threats as external factors PT XYZ is as follow:

1) Backward Integration: (1) the establishment of specific parts related to import material with updating import permit (Alt1), (2) development of local partners (suppliers) in production and quality aspects especially for strategic materials (Alt2)

2) Forward Integration: Develop a one stop service package for airline customers (Alt3)

3) Market development: Development of non-Inflight Catering business (Alt4)

4) Product development: Development of spices and frozen food products (Alt5)

5) Market penetration: (a) build a network with Skyteam members in the provision of flight catering (Alt6), (b) Development of services for catering aircraft LCC (Alt7)

The results of data processing based on expert assessment of PT XYZ which is representative of the head of the company that is Director of Operations, General Manager of Unit CGK, Executive Manager Operation, and Business Development Specialist presented in QSPM Matrix in Table 6.

Table 6: QSPM Matrix

\begin{tabular}{|c|c|c|c|}
\hline No. & Alternative Strategies & TAS & Ranking \\
\hline 1 & $\begin{array}{c}\text { The establishment of specific parts related } \\
\text { to import material }\end{array}$ & 5,000 & 5 \\
\hline 2 & $\begin{array}{c}\text { Development a good partnership of local } \\
\text { suppliers in production and quality aspects } \\
\text { especially for strategic materials }\end{array}$ & 3,500 & 7 \\
\hline 3 & $\begin{array}{c}\text { Developing one stop service package for } \\
\text { airline customers }\end{array}$ & 8,000 & 1 \\
\hline 4 & $\begin{array}{c}\text { Development of non-Inflight Catering } \\
\text { business }\end{array}$ & 7,000 & 2 \\
\hline 5 & $\begin{array}{c}\text { Development of frozen seasoning and food } \\
\text { products }\end{array}$ & 5,500 & 4 \\
\hline 6 & $\begin{array}{c}\text { Build a good network with Skyteam } \\
\text { members in the provision of flight catering }\end{array}$ & 4,500 & 6 \\
\hline 7 & Development of services for LCC & 6,500 & 3 \\
\hline
\end{tabular}

The result of data processing based on expert assessment of PT XYZ which is representative of the leadership of the company. The result of evaluation on QSPM Matrix is known that three alternative business development strategy that best suits the internal condition and external environment of PT XYZ. Alternative strategy is to develop a one-stop service package valued experts in accordance with 


\section{International Journal of Science and Research (IJSR) \\ ISSN (Online): 2319-7064 \\ Index Copernicus Value (2016): 79.57 | Impact Factor (2015): 6.391}

the company's conditions and developed into one of PT XYZ's business development strategy. Alternative strategy The development of non-flight catering business as the 2nd rank on QSPM evaluation result which is followed by alternative strategy of frozen food and frozen product development also need to be taken into account in the development of catering business operated by PT XYZ considering that the market for the catering of flight is captive and requires a period of time long to develop. The alternative strategy of developing local supplier business partners in the aspects of production and quality especially for strategic materials is the weakest alternative strategy according to the expert in determining the business development strategy of PT XYZ Director of Operations, General Manager of Unit CGK, Executive Manager Operation, and Business Development Specialists.

\section{Establishment of Special Materials Import}

PT XYZ has been cooperating with suppliers who import activities for these activities, but there are often obstacles mainly related to material gaps that result in substitution with other materials. Replacement of such material shall be done under the approval of the airline and there shall be one of the airline customers establishing the SLA with financial sanction in the event of material replacement without consent. The current condition of the vacancy frequency of goods often occurs in PT XYZ with very sudden information, thus disrupting operations and resulting in PT $\mathrm{XYZ}$ getting sanction from the airline.

With the establishment of a special section dealing with the procurement of imported materials is expected to reduce the cost of purchases by using delivery channels in cooperation with Garuda Indonesia station located in various countries and can avoid SLA sanction from the airlines served. The import-related sections are concentrated in CGK for procurement of imported materials covering all catering needs of aviation at eight other Inflight Catering units owned by PT XYZ. This may be done by PT XYZ considering that it has been doing import procurement for meat commodities and already has a principle license from the Ministry of Trade of the Republic of Indonesia. Human resources for import and customs activities are now owned by PT XYZ.

\section{Development of Local Business Partners (suppliers)}

Coaching of business partners can be done from upstream production of foodstuffs to be shipped to PT XYZ. The coaching that is done is related to the special production is only supplied to PT XYZ with specifications in accordance with the needs of PT XYZ on some small and medium scale suppliers. This strategy is expected to provide economic value to the company, maintain the sustainability of raw materials, and maintain the consistency of material quality. The coaching of a business partner as a perishable item is inherent to the food safety of the product. Audits related to hygiene and food safety against the rest are carried out periodically by monitoring the progress of improvement from previous audit results.

This realization requires specialized HR professionals who understand the upstream production of a raw material and require investment funds of production facilities that meet hygiene and food safety requirements. Guidance regarding current quality aspects is important to avoid risks related to food poisoning or the adverse side effects of consuming PT $\mathrm{XYZ}$ food products as the final consumer of PT XYZ food products is the international community in general and other state guests and VVIPs on special VVIP flights quality and safety of the product.

\section{Developing One Stop Service Package for Airline Customers}

This strategy prioritizes collaboration among subsidiaries of Garuda Indonesia Airlines. Offering foreign airlines entering Soekarno-Hatta Airport with service packages ranging from ground handling services, initial and passenger transport services, maintenance services, executive lounges, and airline catering. Ground handling services are owned by Gapura Angkasa, a freight service owned by Aerotrans while maintenance service is owned by GMF which is part of Garuda Indonesia. PT XYZ in this case offers flight catering packages and lounge management for passengers. PT XYZ has good facilities and experience for mass production of flight catering and executive lounge with good service.

This package offer allows cooperation for airlines that will enter Indonesia or as an effort to attract foreign airlines who have not yet decided to appoint catering partners in Indonesia such as KLM Royal Dutch Airlines which is still working with catering Malaysia flight in serving flight route KUL-KUL- AMS. Collaboration between subsidiaries of Garuda Indonesia Airlines in this case should be able to create a mutual synegi each other. Soekarno-Hatta International Airport which is the gateway of foreign flights to Indonesia became the right market for this strategy.

\section{Development of Non - Flight Catering Business}

Non-Inflight Catering business development plan has been launched by PT XYZ in the last five years, but there is no good realization related to the plan. PT XYZ in this strategy should focus and provide the same portion of interests as the catering of the aviation sector. This is supported by the development of the food and beverage industry in Indonesia, especially the food industry that provides a distinctive experience for consumers in terms of service, quality, and atmosphere. Dissemination of information related to food products is currently very fast with the social media.

Human resources, facilities, technology and certification have been owned by PT XYZ as a resource in the development of non-flight catering business. This non-flight catering development can be a premium catering for VIP activities packed with better and more attractive packages and services. Another development that can be done is to build business activities for family catering with delivery services. This business development requires a strong information channel as the use of internet-based technology. This strategy is built with web-base technology where all information and transaction activities are done through an attractive and representative website.

Development of Seasonings and Frozen Food Products Technology that can be developed by PT XYZ one of them is frozen food technology. PT XYZ needs to do investi construction facilities to eat the beu or frozen food.

\section{Volume 6 Issue 12, December 2017}




\section{International Journal of Science and Research (IJSR) \\ ISSN (Online): 2319-7064}

Index Copernicus Value (2016): 79.57 | Impact Factor (2015): 6.391

Opportunity of open product development with solid urban community activity so as to prefer the practical food in the presentation. Frozen products are traded on retailers with refrigeration facilities. Consumers just need to reheat the frozen food products. The advantages of frozen food besides being practical are can be stored for longer by adjusting the storage temperature as required for the storage of frozen food.

\section{Building a Network With Skyteam Members}

PT XYZ as part of Garuda Indonesia Airlines which is a member of Skyteam airline alliance becomes a force of PT $\mathrm{XYZ}$ in its business development. Skyteam members work with each other to connect with aviation business development related to share code flight and connecting flight through alliance members.

Some Skyteam airline companies have not yet cooperated with PT XYZ in providing flight catering. This strategy opens opportunities for cooperation to attract new customers who are members of Skyteam. Another advantage in cooperation is related to Garuda Indonesia's executive lounge income managed by PT XYZ. PT XYZ may offer access to Garuda Executive Lounge for Business and First Class passengers to customers who are members of Skyteam. This strategy is also one of Garuda Indonesia's commitment in cooperating with Skyteam member airlines.

\section{Development of Service for Catering of LCC Aircraft}

PT XYZ is currently serving the LCC flights of Citilink flights. The process of doing business is relatively different from the business process to serve full service airlines. Currently, the handling of airline services still joins the domestic Garuda Indonesia flight in activities. The concept of service offered to LCC airlines still has not significantly impacted PT XYZ's revenue. Evaluation of business schemes for LCC flight catering needs further discussion with a special division focusing on LCC flights starting from administrative, marketing, and operational processes.

The other LCC flights served by PT XYZ are Air Asia flights, but are limited to Umrah flights. Air Asia Indonesia currently becomes a big enough customer potential for PT $\mathrm{XYZ}$, but PT XYZ needs to prepare the internal conditions and readiness of human resources to handle LCC aircraft with a more complicated business scheme and highly dependent on passenger appetite which is the determining factor of the above selling rate air.

\section{Conclusion}

Preparation strategy has three stages of the input stage, matching stage and decision-making stage. The input stage in this research is doing anlisis internal factor with VRIO analysis and analysis of external factor with PESTEL analysis. Company resources can be known whether the sumbersaya is valuable, rare, not easily imitated, and has exploited the company so it can diketahi competitive advantage of the company. The PESTEL analysis outlines the company's extensive conditions of political, economic, social, technological, environmental, and legal aspects. The IFE Matrix Score on PT XYZ is 2,611 and the EFE Matrix score at PT XYZ reaches 3,118 indicating that the company has utilized and responded to both internal and external factors of the company.

The result of the matching stage on IE Matrix shows that PT $\mathrm{XYZ}$ is in cell number II which indicates the company is in a position to grow and membagun. The right strategy for matching results is an intensive strategy strategy that is market penetration, market development, and product development or integration strategy that is backward integration, forward integration and horizontal integration. Some alternative strategies that have been prepared are:

1) The establishment of a special section related to the import of disertain materials with renewal of import permit

2) Development of local business partners (suppliers) in the aspects of production and quality, especially for raw materials that are strategic

3) Develop a one stop service package for airline customers.

4) Development of non-flight catering business.

5) Development of spices and frozen food products.

6) Build a network with Skyteam members in the provision of flight catering.

7) Development of services for catering LCC aircraft.

The result of evaluation of QSPM Matrix is known that three alternative of business development strategy that best match with internal condition and external environment of PT XYZ. Alternative strategy is to develop a one-stop service package valued experts in accordance with the company's conditions and developed into one of PT XYZ's business development strategy. Alternative strategy The development of non-flight catering business as the 2nd rank on QSPM evaluation result which is followed by alternative strategy of frozen food and frozen product development also need to be taken into account in the development of catering business operated by PT XYZ considering that the market for the catering of flight is captive and requires a period of time long to develop. Alternative strategy of local supplier business development in the aspect of production and quality especially for strategic raw materials is the weakest alternative strategy according to the expert in determining the business development strategy of PT XYZ.

Further research is needed to determine the success indicators of achieving PT XYZ's scalable business development strategy so that the implementation of the strategy works well. The financial impact of the strategic work program needs to be evaluated for a certain period.

\section{References}

[1] Aubert AE, Frigstad AK. 2007. Strategic analysis of Statoil's international competitiveness [tesis]. Bergern (NO): Norwegian School of Economics and Business Administration.

[2] Barney, J. 1991. Firm resources and sustained competitive advantage. Journal of Management. 7: 99120.

[3] Dahlia, I. 2010. Formulasi strategi bersaing produk maxi PT Adira Multi Finance Indonesia di Area Jabotabek [tesis]. Jakarta (ID): Unieversitas Indonesia [4] Bratvold D. 2014. What is Crowdsourcing?.

\section{Volume 6 Issue 12, December 2017}




\section{International Journal of Science and Research (IJSR) \\ ISSN (Online): 2319-7064}

Index Copernicus Value (2016): 79.57 | Impact Factor (2015): 6.391

[internet]. [Diakses pada 2016 April 27]. Tersedia pada: dailycrowdsource.com/training/crowdsourcing/what-iscrowdsourcing

[4] David, F. 2008. Managemen Strategis. Ed ke-10. Jakarta: Salemba Empat.

[5] David, F. 2013. Strategic Management: Concept and Cases. 14th Ed. England: Pearson Education Limited.

[6] Departemen Jenderal Perhubungan Udara. 2016. Kementrian Perhubungan Republik Indonesia. htthubud.dephub.go.id

[7] Dess, G. Gregory, Lumpkin. G.T, Eisner. Alan. B. 2009, Strategic Management Text \& Cases, 5th edition, Irwin Professional Publisher

[8] Fajar, M. 2012. Perencanaan strategis pt indo American seafood (tahun 2012 - 2016) [tesis]. Bogor: Intitut Pertanian Bogor.

[9] Freddy, Rangkuti. 2006. Teknik Mengukur dan Strategi Meningkatkan Kepuasan Pelanggan. Jakarta: PT Gramedia Pustaka Utama.

[10] Grant, Robert M. 1995. Contemporary Strategy Analysis: Concept Techniques, Application. Massachussetts: Basil Blackwell inc.

[11] Hanson, Dallas. Peter J Dowling et al. 2008. Strategic Management, Thomson, South Melborn, Australia.

[12] Hubbard D. 2007. How to Measure anything: Finding The Value of intangibles in Business. New Jersey: John Wiley \& Sons.

[13] Jones, Peter. 2007. Flight Catering in Becker, H and Grothues, U. 2016. Catering - Mangement Portrait Einer Wachstumbranche in Theorie und Praxis. Behr's Verlag: Hamburg.

[14] Kurniawan, AI. 2009. Perencanaan strategik pt liza herbal internasional [tesis]. Bogor: Intitut Pertanian BogorMarimin, Maghfiroh N. 2010. Aplikasi Teknik Pengambilan Keputusan dalam Manajemen Rantai Pasok. Bogor (ID): IPB Press. Mifflin Company

[15] Pearce \& Robinson (2008). Manajemen Strategis: Formulasi, Implementasi dan Pengendalian. Jakarta: Salemba Empat.

[16] Pohan, KR. 2010. Analisis Strategi Bersaing Pertamina dalam mempertahankan market leader pada persaingan pasar pelumas otomotif [tesis]. Jakarta (ID): Universitas Indonesia

[17]Porter, M.E. 2007. Strategi Bersaing Teknik Menganalisis Industri dan Pesaing, Alih Bahasa: Sigit Suryanto, Tanggerang: Kamirma Publishing Group.

[18] Porter, M.E. 2008. The Five Competitive Forces I Hat Shape Strategy. Harvard Business Review, January.

[19] Purwadi, A. 2004. Perencanaan strategic pt bank negara Indonesia (persero) tbk kantor cabang imam bonjol padang tahun 2004 - 2008 [tesis]. Bogor: Institut Pertanian Bogor.

[20]Purwadi , T. 2012. Pengaruh faktor internal dan eksternal terhadap profitabilitas perusahaan tekstil yang terdaftar di Bursa Efek Indonesia tahun 2005 - 2011 [tesis]. Bogor: Institut Pertanian Bogor.

[21] Robinson, S. 2008. Understanding the Resources Based View: Implication of Methodological Choice and a new Creative Context. Quinsland: Queensland University of Technology.

[22] Rotharmael, F. 2013. Strategic Management: Concepts and Cases. New Yor: MacGraw-Hill
[23] Sholihin, U. 2014. Analisis startegi pemasaran dalam menghadapi persaingan usaha pada perusahaan kain dan sarung tentun ikat cap Sinar Barokah Kediri. Jurnal Cendikia. 12(3): 1-6.

[24] Sumarwan U, Daryanto A, Achsani NA, Fahmi I, Suhendi NN, Lindasari P, Sijabat FDV, Tobing A, Kristiadi A, Hardiyanto AT et al. 2014. Metode Riset Bisnis dan Konsumen. Sumarwan U, editor. Bogor (ID): IPB Press.

[25] Wheelen TL, JD Hunger. 2004. Strategic Management and Business Policy. 9th Ed. New Jersey (US): Prentice Hall International.

\section{Author Profile}

Martiana Kartika Dewi, Post Graduate, School of Business, Bogor Agricultural University, Indonesia.

Prof. Dr. Ir. Bonar Sinaga, School of Business, Bogor Agricultural University, Indonesia.

Ir. Setiadi Djohar, MSM, DBA, School of Business, Bogor Agricultural University, Indonesia. 